\title{
Drum drying process of jabuticaba pulp using corn starch as an additive
}

\section{Processo de secagem em cilindro rotativo de polpa de jabuticaba usando amido de milho como aditivo}

\author{
Larissa Peixoto Nunes ${ }^{1}$, Cristhiane Caroline Ferrari ${ }^{1 *}$ (1), Danielle Ito $^{2}$, \\ Elaine de Cássia Guerreiro Souza ${ }^{1}$, Silvia Pimentel Marconi Germer ${ }^{1}$ \\ ${ }^{1}$ Instituto de Tecnologia de Alimentos (ITAL), Centro de Tecnologia de Frutas e Hortaliças (FRUTHOTEC), \\ Campinas/SP - Brasil \\ ${ }^{2}$ Instituto de Tecnologia de Alimentos (ITAL), Centro de Tecnologia de Embalagem (CETEA), Campinas/SP - Brasil \\ ${ }^{*}$ Corresponding Author: Cristhiane Caroline Ferrari, Instituto de Tecnologia de Alimentos (ITAL), Centro de \\ Tecnologia de Frutas e Hortaliças (FRUTHOTEC), Av. Brasil, 2880, CEP: 13070-178, Campinas/SP - Brasil, \\ e-mail: criscaferrari@gmail.com
}

Cite as: Nunes, L. P., Ferrari, C. C., Ito, D., Souza, E. C. G., \& Germer, S. P. M. (2020). Drum drying process of jabuticaba pulp using corn starch as an additive. Brazilian Journal of Food Technology, 23, e2019166. https://doi.org/10.1590/1981-6723.16619

\begin{abstract}
Jabuticaba is a fruit native to Brazil, appreciated for its flavor and is also very nutritious, but it is a seasonal fruit and highly perishable. Therefore, drying is a good alternative for its conservation. The purpose of this work was to use drum drying to obtain jabuticaba flakes using corn starch as the main carrier agent. The sorption isotherm of the flakes at $25^{\circ} \mathrm{C}$ was also studied, as well as the determination of the critical storage condition and the estimation of product shelf life through the permeability of different packages to the water vapor using mathematical models. The drum drying conditions were: temperature of $144{ }^{\circ} \mathrm{C}$; residence time of 18 seconds; addition of $20 \%$ (dry basis) of corn starch and $0.5 \%$ (d.b.) of glyceryl monostearate. The final product was analyzed with respect to its physicochemical and technological properties. The sorption isotherm of the flakes was determined at $25^{\circ} \mathrm{C}$, using the gravimetric method with saturated solutions $\left(0.11 \leq \mathrm{a}_{\mathrm{w}} \leq 0.84\right)$. After the process, the flakes presented good retention of anthocyanins and total phenolic compounds, besides a high antioxidant activity. The water solubility of the product was around $70 \%$ and the hygroscopicity was approximately $24 \%$. The equilibrium experimental points of the isotherm were better adjusted by the GAB model, with a monolayer moisture value of $12.74 \%$ (w.b) and a critical $a_{w}$ of 0.432 .
\end{abstract}

Keywords: Myrciaria sp.; Sorption isotherms; Storage; Anthocyanins; Antioxidant activity; Phenolic compounds; Technological properties; Shelf life.

\section{Resumo}

A jabuticaba é uma fruta nativa do Brasil, muito apreciada pelo sabor, sendo também muito nutritiva. No entanto, é sazonal e altamente perecível. Portanto, a secagem é uma alternativa que se apresenta para conservação e mais oferta. O presente estudo teve por objetivo empregar o drum drying na obtenção de flocos de jabuticaba, utilizando amido de milho regular como agente carreador principal. Objetivaram-se, também, o levantamento da isoterma de sorção dos flocos $\left(a 5^{\circ} \mathrm{C}\right)$ e, por modelos matemáticos, a determinação da condição crítica de armazenamento, 
bem como do tempo de vida útil por meio da permeabilidade de diferentes embalagens ao vapor de água. As condições do drum drying foram: temperatura de $144{ }^{\circ} \mathrm{C}$; tempo de residência de 18 segundos, adição de $20 \%$ (base seca) de amido de milho regular e $0,5 \%$ (b.s.) de monoestearato de glicerila. O produto final foi analisado quanto a suas propriedades físico-químicas e tecnológicas. Determinou-se a isoterma de sorção dos flocos a $25^{\circ} \mathrm{C}$, empregando-se o método gravimétrico com soluções saturadas $\left(0,11 \leq a_{w} \leq 0,84\right)$. No processo, os flocos apresentaram boa retenção de antocianinas e de compostos fenólicos totais, além de alta atividade antioxidante. A solubilidade em água do produto foi em torno de $70 \%$ e a higroscopicidade, de aproximadamente $24 \%$. Os pontos experimentais de equilíbrio da isoterma foram mais bem ajustados pelo modelo de $G A B$, com valor de umidade da monocamada de $12,74 \%$ e $a_{w}$ crítica de 0,432 .

Palavras-chave: Myrciaria sp.; Isotermas de sorção; Armazenamento; Antocianinas; Atividade antioxidante; Compostos fenólicos; Propriedades tecnológicas; Vida útil.

\section{Introduction}

Jabuticabeira (Myrciaria sp.) is a Brazilian fruit tree, which can be found in several regions of Brazil, but the southeast is the main producer (Sato \& Cunha, 2007). Its fruit, jabuticaba, has high amounts of phenolic compounds and anthocyanins (Oliveira et al., 2018), with a potential beneficial effect on health (anti-inflammatory and anticarcinogenic) due to its antioxidant capacity to combat free radicals and aging of cells (Bueno et al., 2012). It is possible to obtain many products with jabuticaba (pulp, jellies and beverages). Jabuticaba is very popular in Brazil, but its commercialization is compromised due to the short harvest period, as well as its limited post-harvest life (Henrique et al., 2015). Despite its high commercial potential, jabuticaba is still little explored on an industrial scale.

Dehydration is one of the alternatives for the conservation and greater supply of fruits. Drying has many advantages, such as the prolonged shelf-life of the product, the concentration of the nutrients, the easier transportation, storage and commercialization (Celestino, 2010). Drum drying is a promising alternative to obtain fruit flakes since the production is profitable. Moreover, this technique requires smaller amounts of carrier agents compared to other processes, such as spray drying, resulting in a good quality product (Barbosa-Cánovas et al., 2005).

To understand the stability of foods, the knowledge of its behavior about different relative humidities or water activities is important, mainly for dehydrated products. Thus, the sorption isotherms, which relate the moisture contents to the equilibrium water activities at a given temperature, are very useful tools for the stability studies of dehydrated products. The isotherms can provide, through mathematical models, the knowledge of the equilibrium properties as well as the critical storage conditions, helping the packaging design and the shelf-life estimation (Zhang et al., 1996).

In this context, the work aimed to evaluate the properties of the jabuticaba flakes produced by drum drying, using corn starch as the main carrier agent. The other objectives were to establish the critical storage conditions of the flakes from the sorption isotherm at room temperature $\left(25^{\circ} \mathrm{C}\right)$ and to estimate the shelf life of the flakes regarding the moisture gain from the packaging.

\section{Material and methods}

\subsection{Material}

Commercial frozen jabuticaba pulp (Sabará variety), purchased from De Marchi Indústria e Comércio de Frutas Ltda. (Jundiaí, Brazil) was used. The pulp was stored in a freezer at $-18{ }^{\circ} \mathrm{C}$ (Electrolux, São Paulo, Brazil). The process additives were corn starch (Ingredion, Mogi Guaçu, Brazil) and glyceryl monostearate (Synth, Diadema, Brazil). 


\subsection{Methods}

\subsubsection{Characterization of raw material}

Jabuticaba pulp was characterized through the centesimal composition. Moisture content, ash, protein, lipids and sugars were analyzed according to Association of Official Analytical Chemists (2006). Mineral contents were also evaluated (Queiroz et al., 2008). Water activity was determined in a digital hygrometer (Aqualab 3 TE, Decagon Devices Inc, USA), at $25^{\circ} \mathrm{C}$. The $\mathrm{pH}$ was measured using a pH meter (model DM 20, Digimed, São Paulo, Brazil), according to Instituto Adolfo Lutz (2008). Soluble solids were determined using a digital portable refractometer (PAL-A B225259, Atago, Tokyo, Japan). The instrumental color, total phenolic compounds content, anthocyanins content and antioxidant activity were also evaluated and the methods are described in item 2.2.3.

\subsubsection{Drum drying process of the jabuticaba pulp}

The pulp was thawed at room temperature and homogenized in a colloidal mill (REX2-AL, Meteor, São Paulo, Brazil) when the process additives were added: $20 \%$ (d.b.) of corn starch and $0.5 \%$ (d.b.) of glyceryl monostearate. The homogenized pulp was dehydrated in a drum dryer (D139, Richard Simon \& Sons, Nottingham, England). The equipment is provided with a single-cylinder, with two application cylinders, and a drying area of approximately $0.5 \mathrm{~m}^{2}$. The conditions of drum drying were fixed based on a previous study (Tonin et al., 2018): clearance of $0.15 \mathrm{~mm}$ (between the heating and applicator cylinder), pool level of $400 \mathrm{~mL}$, a residence time of 18 seconds and temperature of $144^{\circ} \mathrm{C}$. The dried product, obtained as a film, was flocculated (S508, Fabbe, São Paulo, Brazil) using a 2.5-mm sieve.

\subsubsection{Flake analyses: analytical methodology}

\subsubsection{Color parameters}

Color parameters were obtained using a colorimeter (CR400, Minolta, Osaka, Japan), through the CIELAB system (D65 illuminant). $L^{*}$ lightness $\left(L^{*}=0\right.$ for black and $L^{*}=100$ for white) and chromaticity parameters $\mathrm{a}^{*}$ (green $[-]$ to red $[+]$ ) and $\mathrm{b}^{*}$ (blue $[-]$ to yellow $[+]$ ) were measured.

\subsubsection{Anthocyanin content}

The anthocyanin content of the samples was determined according to the spectrophotometric $\mathrm{pH}$ differential method (Association of Official Analytical Chemists, 2006), which is based on the structural transformation of anthocyanin that occurs with a change in $\mathrm{pH}$ (colored at $\mathrm{pH} 1.0$ and colorless at $\mathrm{pH} 4.5$ ). Absorbance was measured in a spectrophotometer (Agilent Technologies, Cary 60 MY13110012, Richardson, USA) at 520 and $700 \mathrm{~nm}$.

\subsubsection{Total phenolic compounds}

The total phenolic compounds were determined in accordance with the adaptation of Folin Ciocalteau's spectrophotometry method (Benvenuti et al., 2004). Absorbance readings were performed at $750 \mathrm{~nm}$ in the spectrophotometer (Agilent Technologies, Cary 60 MY13110012, Richardson, USA).

\subsubsection{Antioxidant activity (DPPH and ABTS)}

The evaluation of the antioxidant activity by DPPH method (Brand-Williams et al., 1995) is based on the capture of the 2.2-diphenyl-1-picryl-hydrazyl radical (DPPH) by antioxidants, producing a decrease in absorbance at $515 \mathrm{~nm}$, determined using the spectrophotometer (Agilent Technologies, Cary 
60 MY13110012, USA). ABTS method is based on the capture of the 2.20-azinobis (3-ethylbenzothiazoline6-sulfonic acid) diammonium salt $\left(\mathrm{ABTS}^{\circ+}\right.$ ) radical which can be generated by a chemical reaction with potassium persulfate, following the adaptation of the methodology proposed by Rufino et al. (2007). Absorbance readings were done at $734 \mathrm{~nm}$ in the spectrophotometer (Agilent Technologies, Cary 60 MY13110012, USA).

\subsubsection{Bulk density, absolute density and porosity}

The bulk density $\left(\rho_{\text {bulk }}\right)$ of the powders was measured by weighing $1 \mathrm{~g}$ of sample and placing it in a $10 \mathrm{~mL}$ graduated cylinder (Goula \& Adamopoulos, 2004). The absolute density ( $\left.\rho_{a b s}\right)$ was determined in a pycnometer, using $99 \%$ ethanol as the immiscible liquid at $25{ }^{\circ} \mathrm{C}$. Porosity $(\mathcal{E})$ was calculated as follows (Equation 1).

$\varepsilon=1-\frac{\rho_{\text {bulk }}}{\rho_{\text {abs }}}$

\subsubsection{Solubility}

Solubility was determined according to Cano-Chauca et al. (2005). About $2.5 \mathrm{~g}$ of the jabuticaba flakes were added to a centrifuge vessel containing $30 \mathrm{~mL}$ of distilled water. The samples were stirred for $30 \mathrm{~min}$ and centrifuged at $3000 \mathrm{xg}$ for $10 \mathrm{~min}$. Then, $10 \mathrm{~mL}$ aliquot of the supernatant was removed and taken to the oven at $105^{\circ} \mathrm{C}$ for $5 \mathrm{~h}$. The solubility was calculated by weight difference.

\subsubsection{Hygroscopicity}

Hygroscopicity was evaluated based on the method recommended by Cai \& Corke (2000) with some changes. Approximately $1 \mathrm{~g}$ of mango flakes were placed in a container at $25{ }^{\circ} \mathrm{C}$ with a $\mathrm{NaCl}$ saturated solution $(75.29 \% \mathrm{RH})$. Samples were weighed when the equilibrium was reached (after 1 week), and hygroscopicity was calculated according to Equation 2 (Jaya \& Das, 2004).

$\mathrm{H}=\frac{\frac{\Delta \mathrm{m}}{\mathrm{M}}+\mathrm{U}}{1+\frac{\Delta \mathrm{m}}{\mathrm{M}}}$

where $H=$ hygroscopicity (\%); $\Delta m=$ increase in weight of the powder after equilibrium (g); $M=$ initial mass of the powder (g); and $U=$ initial moisture content of the powder (\%).

\subsubsection{Stability of the flakes regarding the storage in different relative humidity: sorption isotherm}

Saturate solutions of different salts were prepared [ $\mathrm{LiCl}, \mathrm{CH}_{3} \mathrm{COOK}, \mathrm{MgCl}_{2}, \mathrm{~K}_{2} \mathrm{CO}_{3}, \mathrm{Mg}\left(\mathrm{NO}_{3}\right)_{2}, \mathrm{KI}$, $\mathrm{NaCl}, \mathrm{KCl}]$ in order to provide relative humidity values between $11 \%$ and $84 \%$. Approximately $1 \mathrm{~g}$ of the drum dried jabuticaba flakes was weighed, in triplicate, in aluminum vials, and equilibrated with these solutions. The containers were stored at room temperature (around $25{ }^{\circ} \mathrm{C}$ ). Samples were weighed periodically until they reached equilibrium, with mass variation $< \pm 0.0001 \mathrm{~g}$, which occurred after 33 days. During this period, the samples were visually observed with respect to color, the occurrence of caking (agglomeration) and microbial growth.

The mathematical models of GAB, BET, Halsey, Oswin and Henderson (Park et al., 2001) were adjusted to the experimental data using Statistica ${ }^{\circledR} 8.0$ software (StatSoft Inc., Tulsa, USA) by non-linear regression. The criteria to choose the best fit were higher coefficients of determinations $\left(\mathrm{R}^{2}\right)$ and mean relative percentage deviation $(\mathrm{P})$ between experimental values $\left(\mathrm{V}_{\mathrm{E}}\right)$ and predicted values $\left(\mathrm{V}_{\mathrm{P}}\right)$ lower than $10 \%$ (Equation 3). 
$P=\frac{100}{n} \sum_{i=1}^{n} \frac{\left|V_{E}-V_{P}\right|}{V_{E}}$

\subsubsection{Estimation of shelf life by water vapor permeability}

The static method to obtain the isotherms allows observations about the physical changes in the product in the equilibrium, at different relative humidities $\left(a_{w}\right)$, determining the critical storage condition. For a powder product, one of the main causes of quality loss is moisture gain. Therefore, its shelf life depends on the level of protection offered by the packaging materials (Yamamoto et al., 2011). According to Robertson (1993), the time to reach a critical condition regarding the moisture gain, due to the permeability of the water vapor through the package, can be obtained through Equation 4.

$\mathrm{t}=\frac{\text { Ws awe } \mathrm{S}}{100 \mathrm{Ap} \mathrm{WVTR}} \ln \frac{(\mathrm{Xe}-\mathrm{Xo})}{(\mathrm{Xe}-\mathrm{Xc})}$

where: awe is the water activity at the storage environment; $\mathrm{S}$ is the slope of the isotherm of the product (assumed linear over the range of Xo and Xc); WVTR is the water vapor transmission rate; Xe is the equilibrium moisture content of the product on dry basis (if it is in contact with the atmosphere outside the package); Xo is the initial moisture content of the product; Xc is the safe storage moisture content of the product on dry basis; Ws is the dry weight of the powder in the package; Ap is the surface area of the package.

Equation 4 was used to estimate the shelf life of the jabuticaba flakes, using the isotherm model chosen, as well as the critical conditions observed in the isotherm test. The following parameters were considered: $25{ }^{\circ} \mathrm{C}$ and $\mathrm{RH}=75 \%$ as environmental condition, a package containing approximately $191 \mathrm{~g}$ flakes (Ws $=185.05 \mathrm{~g}$ of dry solids), surface area $\mathrm{Ap}=0.0225 \mathrm{~m}^{2}$. Xc and Xe were obtained based on the mathematical model of sorption isotherm selected. Two packaging materials were used with different barrier properties, according to Yamamoto et al. (2011): metalized polyester with low-density polyethylene

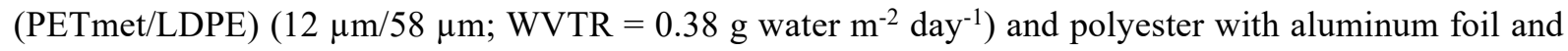
low-density polyethylene (PET/A1/LDPE) $\left(11 \mu \mathrm{m} / 10 \mu \mathrm{m} / 33 \mu \mathrm{m}\right.$; WVTR $<0.01 \mathrm{~g}^{2}$ water $\mathrm{m}^{-2}$ day $\left.^{-1}\right)$. For PET/Al/LDPE packaging, as the transmission rate is lower than $0.01 \mathrm{~g}$ water $\mathrm{m}^{-2} \mathrm{day}^{-1}$, this value was considered for calculation.

\subsubsection{Statistical analysis}

The analyses were performed at least in triplicates and the results were evaluated by analysis of variance (ANOVA), using the software STATISTICA ${ }^{\circledR}$ version 8.0 (Statsoft, Inc., Tulsa, USA). Mean separation was determined using the Tukey test at $5 \%$ level of significance $(p \leq 0.05)$.

\section{Results and discussion}

\subsection{Physicochemical characterization of the raw material}

Table 1 shows that the pulp consists predominantly of water and carbohydrates. In addition, it is low calorie, showing non-significant amounts of lipids and proteins. Several minerals are presented in the jabuticaba pulp mainly potassium. In a similar work, Lima (2009) reported potassium content around $1180 \mathrm{mg} / 100 \mathrm{~g}$ (d.b.) in freeze-dried jabuticaba.

Concerning the total sugars, approximately $78 \%$ are reducing sugars. The presence of these sugars may influence the quality of the dehydrated products, since during the process as well as in the storage, the formation of dark compounds may occur due to the Maillard reaction (Nursten, 2005). Besides, these low-molecular-weight sugars, which have low glass transition temperatures, are responsible for the agglomeration and sticky behavior of powder products along with the storage. In this case, as previously 
mentioned, the use of high-molecular-weight process additives is required (Bhandari et al., 1997), such as corn starch, cassava starch, gums, maltodextrin, among others.

Table 1. Composition of the jabuticaba pulp used in the study.

\begin{tabular}{cccc}
\hline & Energetic value 36 kcal/100 g & \\
\hline Moisture content (\% w.b.) & $90.63 \pm 0.09$ & \multicolumn{2}{c}{ Minerals (mg/100 g d.b.) } \\
\hline Total carbohydrates (g/100 g d.b.) & 94.34 & Calcium & $474.92 \pm 0.11$ \\
\hline Ashs (g/100 g d.b.) & $3.41 \pm 0.10$ & Copper & $3.73 \pm 0.02$ \\
\hline Total lipids (g/100 g d.b.) & $\mathrm{ND}<0.10$ & Iron & $17.07 \pm 0.11$ \\
\hline Proteins (N x 5.75) (g/100 g d.b.) & $2.24 \pm 0.10$ & Phosphor & $873.63 \pm 0.64$ \\
\hline Sugars (g/100 g d.b.) & & Magnesium & $1005.76 \pm 0.11$ \\
\hline Total sugars & $74.38 \pm 2.03$ & Manganese & $35.32 \pm 0.00$ \\
\hline Reducing sugars & $57.84 \pm 0.43$ & Potassium & $13895.73 \pm 53.36$ \\
\hline Non-reducing sugars & $16.54 \pm 2.24$ & Sodium & $233.51 \pm 4.59$ \\
\hline Inverted sugars & $75.24 \pm 2.13$ & Zinc & $16.32 \pm 0.02$
\end{tabular}

\subsection{Physicochemical properties of the raw material and the jabuticaba flakes}

According to Table 2, drum drying was very efficient, resulting in jabuticaba flakes with a moisture content of approximately $2 \%$ (w.b.) and $\mathrm{a}_{\mathrm{w}}$ lower than 0.3 , providing good stability. Labuza (1968) stated that reaction rates, such as enzymatic and non-enzymatic darkening, as well as lipid oxidation, are minimal in aw close to 0.25 . Yamato et al. (2019) reported a moisture content around $1.7 \%$ (w.b.) and $\mathrm{a}_{\mathrm{w}}$ of 0.254 in mango flakes obtained by drum drying, using corn starch as additive. On the other hand, Zea et al. (2013) found higher values of moisture content and $\mathrm{a}_{\mathrm{w}}(5.09 \% \mathrm{w} . \mathrm{b}$. and 0.29 , respectively) for freeze-dried pitaya using $10 \%$ maltodextrin.

The anthocyanin content of the pulp $(158.24 \mathrm{mg} / 100 \mathrm{~g}$ d.b.) was lower than the results pointed out in other studies with jabuticaba. Santos et al. (2010) and Lima et al. (2011) reported anthocyanin values from $367 \mathrm{mg} / 100 \mathrm{~g}$ d.b. to $837 \mathrm{mg} / 100 \mathrm{~g}$ d.b. in fresh fruit, with a predominance of cyanidin-3-glucoside and delphinidin-3-glucoside. The lower content of the pigment observed in the present study, when compared to the fresh fruit, can be associated with the use of a frozen pulp, since the industrial process may promote a partial degradation of the anthocyanins. According to Table 2, the anthocyanin content decreased on drying around $22 \%$. This reduction can be related to the sensitivity of the anthocyanins to the drying temperature (Cavalcanti et al., 2011), besides the addition of process additives to the pulp, incorporating mass in the final product.

Table 2. Physicochemical properties of the pulp and the jabuticaba flakes obtained by drum drying using corn starch as additive.

\begin{tabular}{|c|c|c|}
\hline Physicochemical properties & Pulp & Flakes \\
\hline Moisture content (\% w.b.) & $90.93 \pm 0.01^{\mathrm{a}}$ & $2.11 \pm 0.02^{b}$ \\
\hline $\mathbf{a}_{\mathbf{w}}$ & $0.995 \pm 0.001^{\mathrm{a}}$ & $0.283 \pm 0.001^{b}$ \\
\hline Anthocyanins (mg/100 g d.b.) & $158.24 \pm 2.50^{\mathrm{a}}$ & $123.17 \pm 4.34^{b}$ \\
\hline Total phenolic compounds (mg gallic acid/100 g d.b.) & $2887.30 \pm 43.50^{\mathrm{a}}$ & $2697.59 \pm 6.69^{b}$ \\
\hline \multicolumn{3}{|c|}{ Antioxidant activity ( $\mu \mathrm{mol} \mathrm{TE} / \mathrm{g}$ d.b.) } \\
\hline DPPH method & $311.17 \pm 9.80^{\mathrm{a}}$ & $252.45 \pm 2.20^{b}$ \\
\hline ABTS method & $324.73 \pm 21.49^{\mathrm{a}}$ & $308.40 \pm 3.95^{\mathrm{a}}$ \\
\hline \multicolumn{3}{|c|}{ Color parameters } \\
\hline $\mathbf{L}^{*}$ & $25.88 \pm 0.69^{\mathrm{a}}$ & $23.51 \pm 1.31^{\mathrm{b}}$ \\
\hline$a^{*}$ & $15.12 \pm 0.23^{\mathrm{b}}$ & $25.28 \pm 1.53^{\mathrm{a}}$ \\
\hline $\mathbf{b}^{*}$ & $3.41 \pm 0.07^{\mathrm{b}}$ & $9.09 \pm 0.80^{\mathrm{a}}$ \\
\hline
\end{tabular}

Different letters, in the same line, indicate a significant difference $(p \leq 0.05)$, according to the Tukey test. $\mathrm{a}_{\mathrm{w}}=\mathrm{water}_{\mathrm{activity}}$. $\mathrm{DPPH}=2.2$-diphenyl-1-picryl-hydrazyl radical. ABTS = 2.20-azinobis (3-ethylbenzothiazoline-6-sulfonic acid) diammonium salt. 
The degradation of the anthocyanins may cause a change in the red/purple color to brown coloration. The behavior is related to the binding of anthocyanins molecules with products generated in the Maillard reaction (non-enzymatic darkening), particularly furfural and hydroxymethylfurfural (Pitalua et al., 2010). The reaction occurs with heat in the presence of reducing sugars and proteins, during processing and storage. Water activity also influences the degradation reaction, since the Maillard reaction starts at $\mathrm{a}_{\mathrm{w}}$ higher than 0.2 and it is intensified in the range of 0.5 and 0.75 due to the higher molecular mobility (Fennema, 1996). However, the degradation of the pigment is also influenced by the type of anthocyanin present in the food. Jabuticaba has cyanidins and delphinidins, but cyanidin is the main anthocyanin (Lima, 2009). According to Fleschhut et al. (2006), delphinidins are less stable, since they have more hydroxyl in ring B, being more susceptible to the degradation reactions. Therefore, the characteristic of the anthocyanins present in jabuticaba favors their stability.

Concerning the total phenolic compounds, the content in the pulp (2887 mg gallic acid/100 g d.b.) is close to that reported by Santos et al. (2010), around $2633.5 \mathrm{mg} / 100 \mathrm{~g} \mathrm{(d.b.),} \mathrm{for} \mathrm{jabuticaba} \mathrm{peel} \mathrm{in} \mathrm{natura.} \mathrm{The} \mathrm{loss}$ during the drying process was lower (approximately 7\%). According to Tonon et al. (2010), the non-enzymatic darkening reaction may promote the formation of phenolic compounds. Hence, the small loss of these compounds may also be related to their generation by the Maillard reaction during the drying. Jiménez-Aguilar et al. (2011) reported a slight loss of phenolic compounds in blueberry powder obtained by spray drying with mesquite gum (about 11\%).

The antioxidant activity of the jabuticaba pulp showed a reduction around 19 and 5\% in the drying for DPPH and ABTS methods, respectively (Table 2). This decrease may be related to the sensitivity of some antioxidant compounds to temperatures, such as anthocyanins, vitamin C and others. Ferrari et al. (2013), working with spray drying of blackberry pulp using maltodextrin, obtained antioxidant activity (DPPH method) around $220 \mu \mathrm{mol} \mathrm{TE} / \mathrm{g}$ d.b.

Regarding the instrumental color, parameter $\mathrm{L} *$ of the pulp was very low $(\sim 26)$, showing the dark color of the pulp, characteristic of the jabuticaba peel. $L^{*}$ values for the flakes $(\sim 24)$ were statistically different (at $p \leq 0.05$ ) from the pulp, indicating a slight darkening in the drying. However, some studies performed with fruits of similar colors provided different behaviors. Tonon et al. (2010), working with spray-dried açaí powder, obtained a lighter product with $\mathrm{L}^{*}$ values around 33 . This result can be explained by the greater amount of carrier agents used in the drying study $(6 \% \mathrm{w} / \mathrm{w})$. Ferrari et al. (2012) also reported higher values for parameter $\mathrm{L}^{*}$ (about 39 ) in blackberry powder produced by spray-drying using $25 \%(\mathrm{w} / \mathrm{w})$ of maltodextrin as process additive.

The parameter $a^{*}$ values (red-green) were higher in comparison to $b^{*}$ values (yellow-blue), for the pulp and the flakes, demonstrating the importance of the red color for the product, characteristic of anthocyanins under certain conditions (Davies et al., 2017). The drying promoted an increase in $a^{*}$ and $b^{*}$ values, which is partially related to the water removal and the pigments' concentration. Higher parameter $b^{*}$ values indicate an increase of the yellow color. Ferreira (2017) reported similar behavior in the foam layer drying of jabuticaba pulp, which can be related to the Maillard reaction, resulting in brown compounds, as previously described (Pitalua et al., 2010).

\subsection{Technological properties of the jabuticaba flakes}

Table 3 shows some technological properties of the drum dried jabuticaba flakes. Absolute density corresponds to the real solid density and does not consider the spaces between the particles, in contrast to the bulk density, which takes into account all these spaces. On the other hand, porosity measures the fraction of the total volume which is occupied by the air. Higher porosity values imply greater volume for packaging and greater possibility for product oxidation due to the presence of air (Lewis, 1987). Saifullah et al. (2016) obtained similar porosity values for spray-dried pineapple and mango powder (56 and 53\%, respectively), close to the result observed in the current work (around 57\%), as seen in Table 3. 
Solubility in water is an important technological property, aiming at the application of the ingredient in a food product. Mishra \& Rai (2006) showed that corn starch has a low solubility at $20^{\circ} \mathrm{C}$ (only $1 \%$ ). However, the starch used as an additive during the drum drying undergoes a gelatinization process at the pool level of the equipment (where the formulated pulp is fed) (Valous et al., 2002). According to Mishra \& Rai (2006), the gelatinization of the starch granule promotes the collapse of the molecular arrangement, with consequent loss of its native crystallinity, which results in swelling and solubilization, improving the solubility of the final product. Nevertheless, the solubility of the jabuticaba flakes ( 69\%) (Table 3$)$ is lower than the value pointed out by Tonin et al. (2018) for drum dried mango flakes with corn 3\% starch $(\sim 79 \%)$. This result is probably due to the greater concentration of the additive used in the present study. On the other hand, Chia \& Chong (2015) reported lower solubility $(\sim 51 \%)$ for dragon fruit peel obtained by drum drying, probably due to the presence of insoluble fibers in the raw material.

Table 3. Technological properties of the pulp and the jabuticaba flakes obtained by drum drying using corn starch as additive.

\begin{tabular}{cc}
\hline Property & Jabuticaba Flakes \\
\hline Bulk Density $(\mathrm{g} / \mathrm{mL})$ & $0.4169 \pm 0.0049$ \\
\hline Absolute Density $(\mathrm{g} / \mathrm{mL})$ & $0.9689 \pm 0.0034$ \\
\hline Porosity $(\%)$ & $56.97 \pm 0.52$ \\
\hline Solubility $(\%)$ & $69.15 \pm 0.83$ \\
\hline Hygroscopicity $(\mathrm{g} / 100 \mathrm{~g})$ & $23.52 \pm 0.56$ \\
\hline
\end{tabular}

The hygroscopicity of the drum dried jabuticaba was around $24 \mathrm{~g} / 100 \mathrm{~g}$, which was very close to the values stated by Zotarelli et al. (2017) in their study with spray-dried mango powder with maltodextrin. In a similar work, Germer et al. (2018) reported hygroscopicity values ranging from 19 to $21 \mathrm{~g} / 100 \mathrm{~g}$ for mango powder produced by drum drying with corn starch (5\% d.b.). On the other hand, Ribeiro et al. (2016) obtained hygroscopicity values of approximately $6 \mathrm{~g} / 100 \mathrm{~g}$ in freeze-dried acerola pulp with maltodextrin $(\sim 19 \% \mathrm{w} / \mathrm{w})$. These results show that the process additives used in the drying of fruit pulps may also affect the hygroscopicity of the products, and consequently their stability.

\subsection{Stability: sorption isotherms}

As observed in Figure 1, the jabuticaba flakes stored in the lowest $a_{w}(0.112)$ kept the intense color after 33 days of storage. Besides, they remained dry and free-flowing during this period. As $a_{w}$ increased, the flakes gradually became darker and agglomerated. The main changes were verified for $\mathrm{a}_{\mathrm{w}}$ values higher than 0.432 when the agglomeration process was more pronounced.

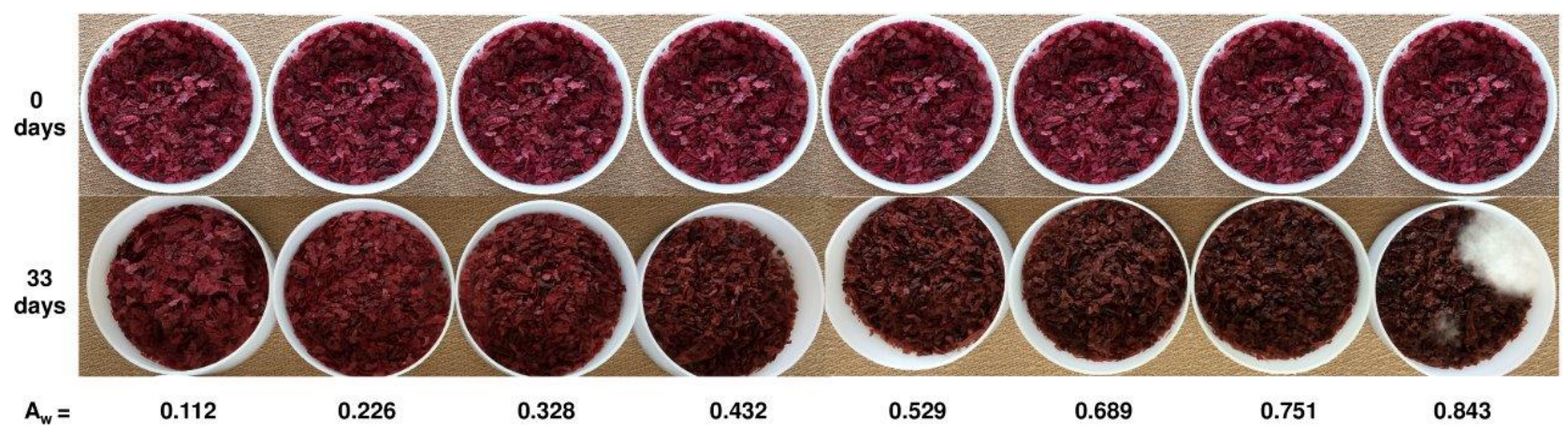

Figure 1. Jabuticaba flakes obtained by drum drying using corn starch, at the equilibrium in the different relative humidities $\left(\mathrm{a}_{\mathrm{w}}\right)$ at $25^{\circ} \mathrm{C}$. 
The agglomeration of the powders is named caking, occurring over the storage time as a result of the surface wetting due to several factors, such as moisture re-equilibration with cooling, recrystallization and solubilization of sugar crystals. Initially, the powders or flakes are dry products with low moisture content, presenting free-flowing characteristics. Throughout the storage, bridges between the particles are formed promoting the development of agglomerates, which are transformed into lumps. In the final stage of caking, the material becomes stickier and the interparticle bridges disappear due to the sample liquefaction. This stage usually involves the solubilization of low molecular weight fractions and may present microbial growth (Aguilera et al., 1995). This behavior was observed in the current study in the sample stored at $\mathrm{a}_{\mathrm{w}}=0.843$ (Figure 1). Thus, $\mathrm{a}_{\mathrm{w}}=0.432 \mathrm{was}$ considered as the critical storage condition for the jabuticaba flakes.

Table 4 shows the parameters obtained for the different mathematical models of sorption isotherms of the jabuticaba flakes. Considering the $\mathrm{R}^{2}$ coefficient, all the models had a great fit to the experimental data $\left(\mathrm{R}^{2}>0.99\right)$, but the GAB model showed the best values of $\mathrm{R}^{2}$. Furthermore, $\mathrm{P}$ values lower than $10 \%$ indicates a good fit of a model to the experimental data. Therefore, BET and Halsey models were not satisfactory. Regarding the BET model, the monolayer values were also inconsistent, higher than 1 , or $100 \%$.

Blahovec (2004) reported that the Oswin model should present $\mathrm{a}>0$ and $1 \geq \mathrm{b}>0$, while for Henderson model $a>0$ and $b \geq 1$. According to the results obtained (Table 4), both models describe the sorption isotherm of the product. However, since P values were the lowest for the GAB model, this model better represents the sorption isotherm of the drum dried jabuticaba flakes with corn starch. In addition, the GAB model, based on the monolayer principle, is the most versatile and suitable model for food sorption isotherms, considering $\mathrm{a}_{\mathrm{w}}$ values from 0.1 to 0.9 (Labuza \& Altunakar, 2007).

Table 4. Parameters for GAB, BET, Halsey, Oswin and Henderson models of sorption isotherms of the jabuticaba flakes obtained by drum drying using starch at $25^{\circ} \mathrm{C}$.

\begin{tabular}{|c|c|c|c|c|c|c|}
\hline Model & Equations & & rameter & & $\mathbf{R}^{2}$ & $P(\%)$ \\
\hline GAB & $\mathrm{MC}_{\mathrm{eq}}=\frac{\mathrm{X}_{\mathrm{m}} \cdot \mathrm{C} \cdot \mathrm{K} \cdot \mathrm{a}_{\mathrm{w}}}{\left(1-\mathrm{K} \cdot \mathrm{a}_{\mathrm{w}}\right) \cdot\left(1-\mathrm{K} \cdot \mathrm{a}_{\mathrm{w}}+\mathrm{C} \cdot \mathrm{K} \cdot \mathrm{a}_{\mathrm{w}}\right)}$ & $\begin{array}{c}\mathbf{X}_{\mathbf{m}} \\
0.1274\end{array}$ & $\begin{array}{c}\mathbf{C} \\
1.3640\end{array}$ & $\begin{array}{c}\mathbf{K} \\
0.9174\end{array}$ & 0.9998 & 1.92 \\
\hline BET & $\mathrm{MC}_{\mathrm{eq}}=\frac{\mathrm{X}_{\mathrm{m}} \cdot \mathrm{C} \cdot \mathrm{a}_{\mathrm{w}}}{\left(1-\mathrm{a}_{\mathrm{w}}\right)} \cdot\left[\frac{1-(\mathrm{n}+1) \cdot\left(\mathrm{a}_{\mathrm{w}}\right)^{\mathrm{n}}+\mathrm{n} \cdot\left(\mathrm{a}_{\mathrm{w}}\right)^{\mathrm{n}+1}}{1-(1-\mathrm{C}) \cdot \mathrm{a}_{\mathrm{w}}-\mathrm{C}\left(\mathrm{a}_{\mathrm{w}}\right)^{\mathrm{n}+1}}\right]$ & $\begin{array}{c}\mathbf{X}_{\mathbf{m}} \\
44.6340\end{array}$ & $\begin{array}{c}\mathbf{C} \\
0.0016\end{array}$ & $\begin{array}{c}\mathbf{n} \\
4.0243\end{array}$ & 0.9950 & 17.29 \\
\hline Halsey & $\mathrm{MC}_{\mathrm{eq}}=\left(\frac{-\mathrm{a}}{\ln \left(\mathrm{a}_{\mathrm{w}}\right)}\right)^{1 / \mathrm{b}}$ & $\stackrel{\mathbf{a}}{0.0790}$ & & $\begin{array}{c}\mathbf{b} \\
1.0398\end{array}$ & 0.9945 & 23.34 \\
\hline Oswin & $\mathrm{MC}_{\mathrm{eq}}=\mathrm{a}\left(\frac{\mathrm{a}_{\mathrm{w}}}{\left(1-\mathrm{a}_{\mathrm{w}}\right)}\right)^{\mathrm{b}}$ & $\stackrel{\mathbf{a}}{0.1270}$ & & $\begin{array}{c}\mathbf{b} \\
0.7777 \\
\end{array}$ & 0.9990 & 8.00 \\
\hline Henderson & $\mathrm{MC}_{\mathrm{eq}}=\left(\frac{-\ln \left(1-\mathrm{a}_{\mathrm{w}}\right)}{\mathrm{b}}\right)^{1 / \mathrm{a}}$ & $\begin{array}{c}\mathbf{a} \\
0.8338\end{array}$ & & $\begin{array}{c}\mathbf{b} \\
3.7475\end{array}$ & 0.9989 & 3.49 \\
\hline
\end{tabular}

where: $\mathrm{MC}_{\mathrm{eq}}=$ equilibrium moisture content ( $\mathrm{g}$ water/g dry basis). $\mathrm{X}_{\mathrm{m}}=$ monolayer moisture content ( $\mathrm{g}$ water/g dry basis). $\mathrm{n}=$ number of molecular layers. $\mathrm{C}, \mathrm{K}, \mathrm{a}, \mathrm{b}=$ constants.

As seen in Figure 2, the increase of the equilibrium moisture is continuous as $\mathrm{a}_{\mathrm{w}}$ increases. According to Brunauer (1943), the GAB model can be classified based on the parameters $\mathrm{K}$ and $\mathrm{C}$ : type II when $0<\mathrm{K} \leq 1$ and $\mathrm{C}>2$; type III when $0<\mathrm{K} \leq 1$ and $0 \leq \mathrm{C} \leq 2$. Therefore, the isotherm of the jabuticaba flakes followed a sigmoidal format (type III), characteristic of sugar-rich food products, since the parameter $\mathrm{K}$ is between 0 and 1 (0.9174), and parameter $\mathrm{C}$ is between 0 and 2 (1.3640). The monolayer moisture content, $\mathrm{X}_{\mathrm{m}}$, was a $0.1274 \mathrm{~g}$ water/g dry basis, which represents the amount of water strongly bound to the matrix food, a condition in which stability is greater (Lins et al., 2017). López-Vidaña et al. (2016) found higher values ( $0.2954 \mathrm{~g}$ water/g dry basis) for jabuticaba flour obtained by conventional air drying. On the other hand, Moreira et al. (2013) obtained $\mathrm{X}_{\mathrm{m}}$ of $0.1171 \mathrm{~g}$ water/g dry basis for freeze-dried mango, while Castoldi et al. (2015) reported $\mathrm{X}_{\mathrm{m}}$ of $0.09 \mathrm{~g}$ water/g dry basis for tomato powder obtained by refractance window. Oliveira et al. (2014) observed $\mathrm{X}_{\mathrm{m}}$ values of 0.18 and $0.09 \mathrm{~g}$ water/g dry basis for freeze-dried yellow mombin with or without $7 \%$ of maltodextrin, respectively. 


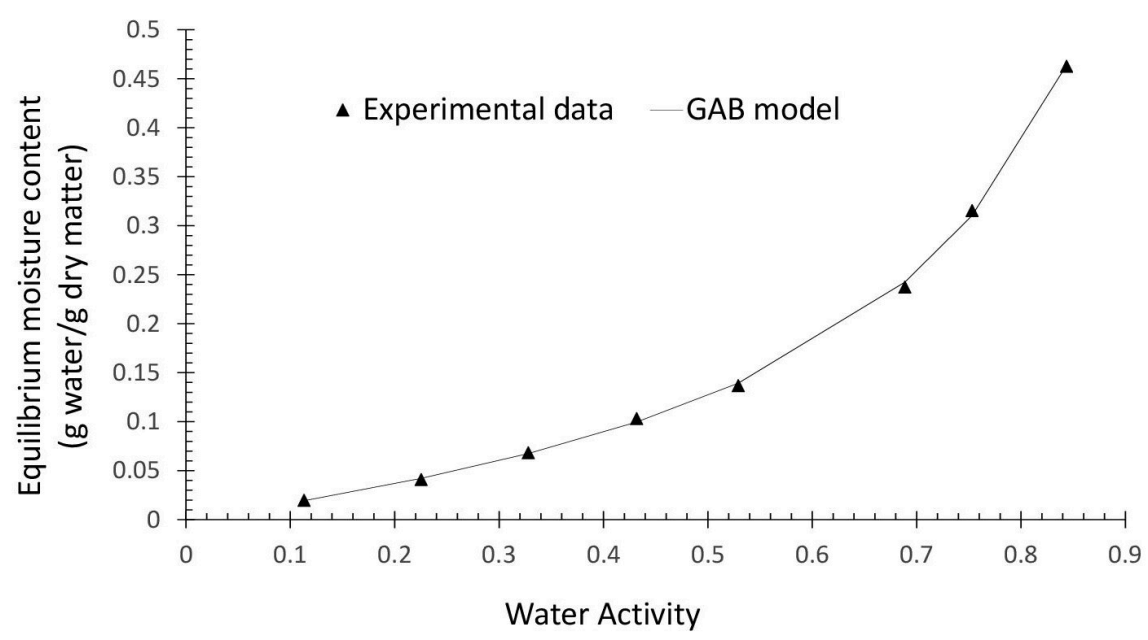

Figure 2. Sorption isotherms of the jabuticaba flakes obtained by drum drying with corn starch at $25{ }^{\circ} \mathrm{C}$ (experimental data and predicted data by GAB model).

\subsubsection{Estimation of shelf life by water vapor permeability}

According to GAB model, Xe for $\mathrm{a}_{\mathrm{w}}=0.75$ (environmental condition) was $0.3154 \mathrm{~g}$ water $/ \mathrm{g}$ dry basis, while Xc observed in the critical condition $\left(\mathrm{a}_{\mathrm{w}}=0.432\right)$ was $0.1031 \mathrm{~g} / \mathrm{g}$ dry basis. As previously discussed, this was the critical condition determined during the evaluation of sorption isotherm of the jabuticaba flakes. Thus, for PETmet/LDPE package, the time for the flakes to reach the critical condition was 6.45 days. On the other hand, for PET/A1/LDPE package, this time was 245 days (about 8 months). It is important to mention that this time can be even higher since the highest water vapor permeability rate was used for this material $\left(\right.$ WVTR $=0.01 \mathrm{~g} \mathrm{water}^{-2}$ days $\left.^{-1}\right)$ (item 2.2.5). Yamato et al. (2019) reported higher values for drum dried mango flakes produced with maltodextrin or corn starch and stored in the same packaging material (1000 g capacity). The use of PETmet/LDPE and PET/Al/LDPE packages resulted in approximately 12 and 450 days of shelf life, respectively, for both products. It is important to point out these results are estimations, since they were obtained with mathematical models, taking into account only the moisture gain. However, they indicate the importance of a high water vapor barrier material for the packaging of drum dried jabuticaba flakes, which have low water activity and high hygroscopicity. Moreover, some transformations occur along with the storage of the product, such as nutrient degradation, sensory changes, among others, limiting the product shelf life. Therefore, stability studies should be performed for a more accurate determination.

\section{Conclusions}

The study demonstrated that it is possible to obtain jabuticaba flakes by drum drying from the commercial pulp. The process resulted in good retention of anthocyanins, phenolic compounds and antioxidant activity. Regarding the instrumental color, the flakes presented a slight darkening and increase of $\mathrm{a}^{*}$ and $\mathrm{b}^{*}$ parameters, indicating a concentration of the pigments. The isotherm of the jabuticaba flakes at $25{ }^{\circ} \mathrm{C}$ followed a sigmoidal format (type III), characteristic of sugar-rich products. GAB model had the best fit to the experimental data and the monolayer water content was $0.1274 \mathrm{~g}$ water $/ \mathrm{g}$ dry basis. The product showed remarkable agglomerations and darkening in $\mathrm{a}_{\mathrm{w}}$ higher than 0.432 . The shelf life estimation, based on the sorption isotherms, showed that PET/Al/LDPE film can protect the product for more than 8 months. 


\section{Acknowledgements}

The authors are grateful to De Marchi Indústria e Comércio de Frutas Ltda. for providing the jabuticaba frozen pulp.

\section{References}

Aguilera, M. J., Del Valle, J. M., \& Karel, M. (1995). Caking phenomena in amorphous food powder. Trends in Food Science \& Technology, 6(5), 149-155. http://dx.doi.org/10.1016/S0924-2244(00)89023-8

Association of Official Analytical Chemists - AOAC. (2006). Official methods of analysis of the Association of Official Analytical Chemists (18th ed.). Maryland: AOAC Press.

Barbosa-Cánovas, G. V., Ortega-Rivas, E., Juliano, P., \& Yan, H. (2005). Food powders: Physical properties, processing, and functionality. Dordrecht: Kluwer Academic/Plenum Publishers.

Benvenuti, S., Pellati, F., Melegari, M., \& Bertelli, D. (2004). Polyphenols, anthocyanins, ascorbic acid and radical scavenging activity of Rubus, Ribes, and Aronia. Journal of Food Science, 69(3), 164-169. http://dx.doi.org/10.1111/j.13652621.2004.tb13352.x

Bhandari, B. R., Datta, N., \& Howes, T. (1997). Problems associated with spray drying of sugar-rich foods. Drying Technology, 15(2), 671-684. http://dx.doi.org/10.1080/07373939708917253

Blahovec, J. (2004). Sorption isotherms in materials of biological origin mathematical and physical approach. Journal of Food Engineering, 65(4), 489-495. http://dx.doi.org/10.1016/j.jfoodeng.2004.02.012

Brand-Williams, W., Cuvelier, M. E., \& Berset, C. (1995). Use of a free radical method to evaluate antioxidant activity. Lebensmittel-Wissenschaft + Technologie, 28(1), 25-30. http://dx.doi.org/10.1016/S0023-6438(95)80008-5

Brunauer, S. (1943). The absorption of the gases and vapors: Physical adsorption. Princeton: Princeton University Press.

Bueno, J. M., Ramos-Escudero, F., Sáez-Plaza, P., Muñoz, A. M., José Navas, M., \& Asuero, A. G. (2012). Analysis and antioxidant capacity of anthocyanin pigments. Part II: Chemical structure, color, and intake of anthocyanins. Critical Reviews in Analytical Chemistry, 42(2), 102-125. http://dx.doi.org/10.1080/10408347.2011.632312

Cai, Y. Z., \& Corke, H. (2000). Production and properties of spray-dried Amaranthus betacyanin pigments. Journal of Food Science, 65(7), 1248-1252. http://dx.doi.org/10.1111/j.1365-2621.2000.tb10273.x

Cano-Chauca, M., Stringheta, P. C., Ramos, A. M., \& Cal-Vidal, J. (2005). Effect of the carriers on the microstructure of mango powder obtained by spray drying and its functional characterization. Innovative Food Science \& Emerging Technologies, 6(4), 420-428. http://dx.doi.org/10.1016/j.ifset.2005.05.003

Castoldi, M., Zotarelli, M. F., Durigon, A., Carciofi, B. A. M., \& Laurindo, J. B. (2015). Production of tomato powder by refractance window drying. Drying Technology, 33(12), 1463-1473. http://dx.doi.org/10.1080/07373937.2014.989327

Cavalcanti, R. N., Santos, D. T., \& Meireles, M. A. A. (2011). Non-thermal stabilization mechanisms of anthocyanins in model and food systems-An overview. Food Research International, 44(2), 499-509. http://dx.doi.org/10.1016/j.foodres.2010.12.007 Celestino, S. M. C. (2010). Princípios de secagem de alimentos. Planaltina: Embrapa Cerrados.

Chia, S. L., \& Chong, G. H. (2015). Effect of drum drying on physico-chemical characteristics of dragon fruit peel (Hylocereus polyrhizus). International Journal of Food Engineering, 11(2), 285-293. http://dx.doi.org/10.1515/ijfe-2014-0198

Davies, K. M., Schwinn, K. E., \& Gould, K. S. (2017). Anthocyanins. In B. Thomas, B. G. Murray \& D. J. Murphy (Eds.), Encyclopedia of applied plant sciences (2nd ed). Amsterdam: Elsevier.

Fennema, O. R. (1996). Water and ice. In O. R. Fennema (Ed.), Food chemistry. New York: Marcel Dekker.

Ferrari, C. C., Germer, S. P. M., \& Aguirre, J. M. (2012). Effects of spray-drying conditions on the physicochemical properties of blackberry powder. Drying Technology, 30(2), 154-163. http://dx.doi.org/10.1080/07373937.2011.628429

Ferrari, C. C., Germer, S. P. M., Alvim, I. D., \& Aguirre, J. M. (2013). Storage stability of spray-dried blackberry powder produced with maltodextrin or gum arabic. Drying Technology, 31(4), 470-478. http://dx.doi.org/10.1080/07373937.2012.742103

Ferreira, M. N. (2017). Estudo da secagem de jabuticaba (polpa e casca) pelo método de camada de espuma (Dissertação de mestrado). Universidade Federal de Goiás, Goiânia.

Fleschhut, J., Kratzer, F., Rechkemmer, G., \& Kulling, S. E. (2006). Stability and biotransformation of various dietary anthocyanins in vitro. European Journal of Nutrition, 45(1), 7-18. PMid:15834757. http://dx.doi.org/10.1007/s00394-005-0557-8

Germer, S. P. M., Tonin, I. P., Aguirre, J. M., Alvim, I. D., \& Ferrari, C. C. (2018). Influence of process variables on the drum drying of mango pulp. Drying Technology, 36(12), 1-13. http://dx.doi.org/10.1080/07373937.2017.1410707

Goula, A. M., \& Adamopoulos, K. G. (2004). Spray drying of tomato pulp: Effect of feed concentration. Drying Technology, 22(10), 2309-2330. http://dx.doi.org/10.1081/DRT-200040007

Henrique, C. M., Prati, P., Parisi, M. M. C., \& Tavares, S. (2015). Determination of shelf life of jaboticaba's fruits cv. Sabará. Brazilian Journal of Biosystems Engineering, 9(4), 320-327. http://dx.doi.org/10.18011/bioeng2015v9n4p320-327

Instituto Adolfo Lutz - IAL. (2008). Métodos físico-químicos para análise de alimentos (4. ed.). São Paulo: IAL.

Jaya, S., \& Das, H. (2004). Effect of maltodextrin, glycerol monostearate and tricalcium phosphate on vacuum dried mango powder properties. Journal of Food Engineering, 63(2), 125-134. http://dx.doi.org/10.1016/S0260-8774(03)00135-3 
Jiménez-Aguilar, D. M., Ortega-Regules, A. E., Lozada-Ramírez, J. D., Pérez-Pérez, M. C. I., Vernon-Carter, E. J., \& WeltiChanes, J. (2011). Color and chemical stability of spray-dried blueberry extract using mesquite gum as wall material. Journal of Food Composition and Analysis, 24(6), 889-894. http://dx.doi.org/10.1016/j.jfca.2011.04.012

Labuza, T. P. (1968). Sorption phenomena in foods. Food Technology, 22(3), 263-272.

Labuza, T. P., \& Altunakar, L. (2007). Water activity prediction and moisture sorption isotherms. In G. Barbosa-Canovas, A. J. Fontana Junior, S. J. Schmidt, \& T. P. Labuza (Eds.), Water activity in foods: Fundamentals and applications. New York: Blackwell Publishing. http://dx.doi.org/10.1002/9780470376454.ch5.

Lewis, M. J. (1987). Physical properties of foods and food processing systems. Chichester: Ellis Horwood.

Lima, A. J. B. (2009). Caracterização e atividade antioxidante da jabuticaba [Myrciaria cauliflora (Mart.) O. Berg] (Tese de doutorado). Universidade Federal de Lavras, Lavras.

Lima, A. J. B., Correa, A. D. C., Saczk, A. A., Martins, M. P., \& Castilho, R. O. (2011). Anthocyanins, pigment stability and antioxidant activity in jabuticaba [Myrciaria cauliflora (Mart.) O. Berg]. Revista Brasileira de Fruticultura, 33(3), 877-887. http://dx.doi.org/10.1590/S0100-29452011000300023

Lins, A. D. F., Rocha, A. P. T., Gomes, J. P., Feitosa, R. M., Araujo, G. T., \& Santos, D. (2017). Adsorption isotherms of the red mombin powder produced in spouted bed dryer. Revista Brasileira de Engenharia Agrícola e Ambiental, 21(8), 562-567. http://dx.doi.org/10.1590/1807-1929/agriambi.v21n8p562-567

López-Vidaña, E. C., Rojano, B. A., Figueroa, I. P., Zapata, K., \& Cortés, F. B. (2016). Evaluation of the sorption equilibrium and effect of drying temperature on the antioxidant capacity of the jaboticaba (Myrciaria cauliflora). Chemical Engineering Communications, 203(6), 809-821. http://dx.doi.org/10.1080/00986445.2015.1107721

Mishra, S., \& Rai, T. (2006). Morphology and functional properties of corn, potato and tapioca starches. Food Hydrocolloids, 20(5), 557-566. http://dx.doi.org/10.1016/j.foodhyd.2005.01.001

Moreira, T. B., Rocha, E. M. F. F., Afonso, M. R. A., \& Costa, J. M. C. (2013). Comportamento das isotermas de adsorção do pó da polpa de manga liofilizada. Revista Brasileira de Engenharia Agrícola e Ambiental, 17(10), 1093-1098. http://dx.doi.org/10.1590/S1415-43662013001000011

Nursten, H. E. (2005). The Maillard reaction: Chemistry, biochemistry, and implications. Reading: Royal Society of Chemistry. Oliveira, F. C., Marques, T. R., Machado, G. H. A., Carvalho, T. C. L., Caetano, A. A., Batista, L. R., \& Correa, A. D. (2018). Jabuticaba skin extracts: Phenolic compounds and antibacterial activity. Brazilian Journal of Food Technology, $21(0), \mathrm{e} 2017108$. http://dx.doi.org/10.1590/1981-6723.10817

Oliveira, G. S., Costa, J. M. C., \& Afonso, M. R. A. (2014). Caracterização e comportamento higroscópico do pó da polpa de cajá liofilizada. Revista Brasileira de Engenharia Agrícola e Ambiental, 18(10), 1059-1064. http://dx.doi.org/10.1590/18071929/agriambi.v18n10p1059-1064

Park, K. J., Bin, A., \& Brod, F. P. R. (2001). Obtenção das isotermas de sorção e modelagem matemática pêra Bartlett (Pyrus sp.) com e sem desidratação osmótica. Ciência e Tecnolologia de Alimentos, 21(1), 73-77. http://dx.doi.org/10.1590/S010120612001000100016

Pitalua, E., Jimenez, M., Vernon-Carter, E. J., \& Beristain, C. I. (2010). Antioxidative activity of microcapsules with beetroot juice using gum arabic as wall material. Food and Bioproducts Processing, 88(2-3), 253-258. http://dx.doi.org/10.1016/j.fbp.2010.01.002

Queiroz, V. A. V., Berbert, P. A., Molina, M. A. B., Gravina, G. A., Queiroz, L. R., \& Silva, J. A. (2008). Qualidade nutricional de goiabas submetidas aos processos de desidratação por imersão-impregnação e secagem complementar por convecção. Food Science and Technology, 28(2), 329-340. http://dx.doi.org/10.1590/S0101-20612008000200010

Ribeiro, L. C., Costa, J. M. C., \& Afonso, M. R. A. (2016). Hygroscopic behavior of lyophilized acerola pulp powder. Revista Brasileira de Engenharia Agrícola e Ambiental, 20(3), 269-274. http://dx.doi.org/10.1590/1807-1929/agriambi.v20n3p269-274 Robertson, G. L. (1993). Food package: Principles and practice. New York: Marcel Dekker.

Rufino, M. S. M., Alves, R. E., Brito, E. S., Moraes, S. M., Sampaio, C. G., Pérez-Jiménez, J., \& Saura-Calixto, F. G. (2007). Metolodogia científica: Determinação da atividade antioxidante total em frutas pela captura do radical livre ABTS•+. Fortaleza: Embrapa Agroindústria Tropical.

Saifullah, M., Yusof, Y. A., Chin, N. L., \& Aziz, M. G. (2016). Physicochemical and flow properties of fruit powder and their effect on the dissolution of fast dissolving fruit powder tablets. Powder Technology, 301, 396-404.

http://dx.doi.org/10.1016/j.powtec.2016.06.035

Santos, D. T., Veggi, P. C., \& Meireles, M. A. A. (2010). Extraction of antioxidant compounds from Jabuticaba (Myrciaria cauliflora) skins: Yield, composition and economical evaluation. Journal of Food Engineering, 101(1), 23-31. http://dx.doi.org/10.1016/j.jfoodeng.2010.06.005

Sato, A. C. K., \& Cunha, R. L. (2007). Influência da temperatura no comportamento reológico da polpa de jabuticaba. Food Science and Technology, 27(4), 890-896. http://dx.doi.org/10.1590/S0101-20612007000400033

Tonin, I. P., Ferrari, C. C., Silva, M. G., Berto, M. I., Oliveira, K. L., Silva, V. M., \& Germer, S. P. M. (2018). Performance of different process additives on the properties of mango powder obtained by drum drying. Drying Technology, 36(3), 355-365. http://dx.doi.org/10.1080/07373937.2017.1334000

Tonon, R. V., Brabet, C., \& Hubinger, M. D. (2010). Anthocyanin stability and antioxidant activity of spray-dried açai (Euterpe oleracea Mart.) juice produced with different carrier agents. Food Research International, 43(3), 907-914. http://dx.doi.org/10.1016/j.foodres.2009.12.013 
Valous, N. A., Gavrielidou, M. A., Karapantsios, T. D., \& Kostoglou, M. (2002). Performance of a double drum dryer for producing pregelatinized maize starches. Journal of Food Engineering, 51(3), 171-183. http://dx.doi.org/10.1016/S02608774(01)00041-3

Yamamoto, E. S., Ito, D., Alvez, R. M. V., Goza, A. C. M., \& Moreira, C. Q. (2011, Ago). Estudo de vida útil acelerado versus modelagem matemática: Avaliação da técnica mais adequada para determinação da vida útil de produtos sensíveis à umidade. In CIIC 2011, $5^{\circ}$ Congresso Interinstitucional de Iniciação. Campinas: Instituto de Tecnologia de Alimentos. Retrieved in 2019 , October 9, from http://www2.aptaregional.sp.gov.br/ciic2017/anais2011.html

Yamato, M. A. C., Silva, V. M., Souza, E. C. G., Ferrari, C. C., \& Germer, S. P. M. (2019). Stability of mango flakes obtained by drum drying with different additives. Drying Technology, http://dx.doi.org/10.1080/07373937.2019.1571505

Zea, L. P., Yusof, Y. A., Aziz, M. G., Ling, C. N., \& Amin, N. A. M. (2013). Compressibility and dissolution characteristics of mixed fruit tablets made from guava and pitaya fruit powders. Powder Technology, 247, 112-119. http://dx.doi.org/10.1016/j.powtec.2013.06.032

Zhang, X., Liu, X., Gu, D., Zhou, W., Wang, R., \& Liu, P. (1996). Desorption isotherms of some vegetables. Journal of the Science of Food and Agriculture, 70(3), 303-306. http://dx.doi.org/10.1002/(SICI)1097-0010(199603)70:3<303::AIDJSFA494>3.0.CO;2-A

Zotarelli, M. F., Silva, V. M., Durigon, A., Hubinger, M. D., \& Laurindo, J. B. (2017). Production of mango powder by spray drying and cast-tape drying. Powder Technology, 305, 447-454. http://dx.doi.org/10.1016/j.powtec.2016.10.027

Funding: None. 